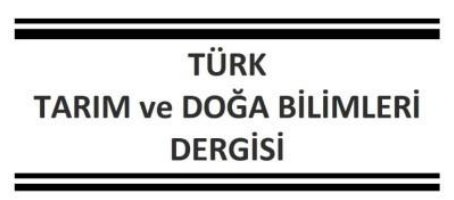

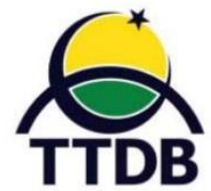

www.dergipark.gov.tr/turkjans

Araştırma Makalesi

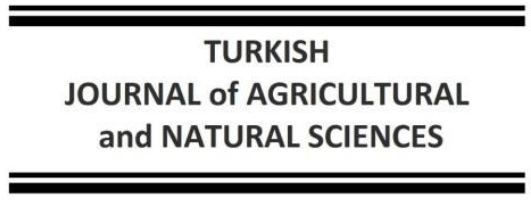

and NATURAL SCIENCES

\title{
Tokat'tan Toplanan İki Yenen Doğal Mantar (Pleurotus eryngii ve Lepista nuda) Örneklerindeki Ağır Metal Seviyeleri Üzerine Bir Çalışma
}

\author{
Hakan IŞIK ${ }^{1 *}$, Aydın Şükrü BENGÜ², Handan ÇINAR YILMAZ², Ibrahim TÜRKEKUL ${ }^{3}$ \\ ${ }^{* 1}$ Tokat M. Emin Saraç Anadolu İmam Hatip Lisesi, 60030, Tokat, Türkiye \\ ${ }^{2}$ Bingöl Üniversitesi, Sağlık Hizmetleri Meslek Yüksekokulu, Tıbbi Hizmetler ve Teknikler Bölümü, Tıbbi \\ Laboratuvar Teknikleri Programı, 12000, Bingöl, Türkiye \\ ${ }^{3}$ Tokat Gaziosmanpaşa Üniversitesi, Fen Edebiyat Fakültesi, Biyoloji Bölümü, 60250, Tokat, Türkiye \\ *Sorumlu Yazar: hakanbiyoloji@gmail.com
}

Geliş Tarihi: 02.05.2020, Düzeltme Geliş Tarihi: 07.01.2021, Kabul Tarihi: 10.01.2021

\section{Öz}

Ormanlık veya çayırlık alanlarda doğal olarak yetişen yenen mantarlar maliyetinin düşük olması ve özel bir lezzete sahip olmaları dolayısıyla tüm dünyada popüler gıda maddeleri olarak toplanmakta ve tüketilmektedir. Ancak bünyelerinde birçok ağır metalleride toplayabildiklerinden dolayı biyoindikatör olarak kullanılmaktadırlar. Mevcut bu çalışmada amacımız Tokat yöresinin farklı lokalitelerinden toplanan Pleurotus eryngii (DC.) Quél., ve Lepista nuda (Bull.) Cooke örneklerindeki bazı ağır metallerin ( $\mathrm{Ni}, \mathrm{Fe}, \mathrm{Cu}, \mathrm{Zn}, \mathrm{Al}, \mathrm{Co}, \mathrm{Mn}$, $\mathrm{Cr}$ ve $\mathrm{Cd}$ ) konsantrasyonlarını tespit etmektir. Mantar örneklerinin ağır metal içerikleri Atomik Absorbsiyon Spektrofotometresi (AAS) cihazı ile belirlenmiştir. Çalışmalar sonucunda mantar örneklerinde 0,079 mg/kg ile $71,750 \mathrm{mg} / \mathrm{kg}$ arasında değişen miktarlarda ağır metal tespit edilmiştir. Tüm mantar örneklerinde demir 9,450 ile $71,750 \mathrm{mg} / \mathrm{kg}$ arasında değişen konsantrasyonlar ile miktarı en yüksek olan mineral olarak ölçülmüştür ve bunu değişik oranlar ile alüminyum ve çinko takip etmiştir. Tüm örneklerde miktarı en az olan mineraller $\mathrm{Ni}, \mathrm{Co}$, $\mathrm{Cr}$ ve $\mathrm{Cd}$ olmuştur. Pleurotus eryngii'nin kirli örneklerdeki mineral miktarının temiz örneklerinden daha fazla olduğu belirlenmiştir. Ancak Lepista nuda'nın temiz örneklerinde $\mathrm{Ni}, \mathrm{Zn}, \mathrm{Co}, \mathrm{Cr}$; kirli örneklerinde ise $\mathrm{Fe}, \mathrm{Cu}, \mathrm{Al}$, $M n$ ve $C d$ daha yüksek miktarda tespit edilmiştir.

Anahtar kelimeler: AAS, ağır metal, çevre kirliliği, doğal yenen mantarlar, Tokat

\section{A Study on Heavy Metal Levels in Two Wild Edible Mushroom (Pleurotus eryngii ve Lepista nuda) Samples Collected from Tokat}

\begin{abstract}
The mushrooms that are naturally grown in woodland or meadow areas are collected and consumed as popular food items all over the world because of their low cost and special taste. However, they are used as bioindicators because they can collect many heavy metals in their bodies. In this present study, our aim is to determine the concentrations of some heavy metals ( $\mathrm{Ni}, \mathrm{Fe}, \mathrm{Cu}, \mathrm{Zn}, \mathrm{Al}, \mathrm{Co}, \mathrm{Mn}, \mathrm{Cr}$ and $\mathrm{Cd}$ ) in the samples of Pleurotus eryngii (DC.) Quél. and Lepista nuda (Bull.) Cooke collected from different localities of Tokat region. The heavy metal contents of the mushroom samples were determined with Atomic Absorption Spectrophotometric instrument (AAS). As a result of studies, heavy metal was detected in the mushroom samples ranging from 0,079 to $71,750 \mathrm{mg} / \mathrm{kg}$. Fe was measured as the highest mineral with concentrations ranging from 9,450 to $71,750 \mathrm{mg} / \mathrm{kg}$ in all mushroom samples, and followed by $\mathrm{Al}$ and $\mathrm{Zn}$ with different rates. The least amount of minerals in all samples were $\mathrm{Ni}, \mathrm{Co}, \mathrm{Cr}$ and $\mathrm{Cd}$. It is determined that the amount of minerals in dirty samples of Pleurotus eryngii is higher than clean samples. However, in the clean examples of Lepista nuda $\mathrm{Ni}, \mathrm{Zn}, \mathrm{Co}, \mathrm{Cr}$; also in dirty samples, $\mathrm{Fe}, \mathrm{Cu}, \mathrm{Al}, \mathrm{Mn}$ and $\mathrm{Cd}$ were detected in higher amounts.
\end{abstract}

Key words: AAS, heavy metal, environmental pollution, wild edible mushrooms, Tokat 


\section{Giriş}

Mantarlar protein, lif, vitamin (özellikle B grubuna ait), mineral, aminoasit, doymamış yağ asitleri ve çeşitli aromatik maddeler bakımından değerli besin kaynaklarıdır. Yağ ve kalori oranının düşük, ancak protein oranının yüksek olması yönüyle özellikle vejetaryen ve protein açısından zengin bir diyetle beslenmek isteyen insanlar için sağlıklı bir gıda olarak önem kazanmıştır (Pekşen ve ark., 2008; Orsine ve ark., 2012; Valverde ve ark., 2015; Bengü ve ark., 2019). Geleneksel Çin tıbbında uzun yıllardan beri kullanılan mantarlar, günümüzde başta Avrupa ve Asya ülkeleri olmak üzere birçok ülkede popüler gıda maddeleri haline gelmiştir (Manzi ve ark., 2001). Dünyada tespit edilen yaklaşık 10 bin civarındaki makromantar türlerinin 5020'si yenilebilir özellik göstermektedir (Pekşen, 2013). Mantarların üretmiş olduğu kimyasal maddeler sayesinde bazı hastalıkların (kanser, hipertansiyon, hiperkolesterolemi gibi) önlenmesinde faydalı olduğu ve ayrıca antibakteriyel ve antiviral özelliklere sahip oldukları da bildirilmiştir (Ita ve ark., 2006).

Ağır metaller, genellikle $5 \mathrm{~g} / \mathrm{cm}^{31}$ den daha fazla özgül yoğunluğa sahip olan, çevreyi ve canlı organizmaları olumsuz etkileyen metaller olarak tanımlanabilir (Järup, 2003). Bu ağır metallerden bazıları (demir ve çinko gibi) biyolojik öneme sahiptir ve insan sağlığının korunması için gereklidir. Ancak yüksek miktarlarda toksik etkileri vardır. $\mathrm{Pb}, \mathrm{Cd}, \mathrm{As}, \mathrm{Hg}$ gibi ağır metallerin ise insanlarda bilinen biyokimyasal ve fizyolojik etkilerinin olmadığı, çok düşük konsantrasyonlarda bile toksik etkilerinin olabileceği bildirilmiştir (Duruibe ve ark., 2007). Ekosistemde uzun süre kalabilen ağır metaller çevrede olduğu gibi canlı bünyesinde de birikirler (özellikle yağ ve kemik dokularında), ve yavaş bir şekilde vücuda salınarak önemli sorunlara yol açarlar. Bu metaller ve onların bileşikleri beyin, böbrek, akciğerler ve karaciğer gibi organların çalışmasına zarar verebilir. Uzun süreli maruz kalmalarda ise kanser, multiple skleroz, Parkinson, Alzheimer, kas distrofisi gibi hastalıklara sebep olabilirler. Mantarlar yaşadıkları ortamdan bazı metalleri kolay bir şekilde bünyelerine alabilme mekanizmalarına sahip olduklarından dolayı sebze, meyve ve diğer tarımsal ürünlere göre daha fazla miktarda metal konsantrasyonuna sahip olabilirler. Yapılan çalışmalar bazı makromantar türlerinin demir, kurşun, cıva, kadmiyum, bakır, krom, manganez, çinko, nikel ve alüminyum gibi ağır metalleri büyük miktarlarda bulundurduklarını göstermiştir (Kalač
2001; Järup 2003; Ita ve ark., 2006; Guerra ve ark., 2012; Širić et al., 2016; Kupchyk 2018).

Bu çalışmanın amacı doğal olarak yetişen ve yenen $P$. eryngii ve $L$. nuda örneklerindeki ağır metal içeriğini tespit etmek ve mantarların kimyasal yapısını belirlemeye yönelik yapılan çalışmalara katkıda bulunmaktır.

\section{Materyal ve Metot}

Ağır metal içeriği tespit edilecek olan $P$. eryngii ve $L$. nuda'ya ait mantar örnekleri Tokat yöresinin farklı lokalitelerinden toplanmıştır. Mantar örneklerine ait bazı özellikler Çizelge 1'de gösterilmiştir. Laboratuvar ortamına getirilen makromantar örnekleri kaba kirler temizlendikten sonra bir ısıtıcı yardımıyla kurutulmuştur ve bir parçalayıcı yardımıyla toz haline getirilmiştir. Ağır metal analizleri için Atomik Absorbsiyon Spektrofotometresi (AAS) cihazı (Perkin Elmer AAnalyst ${ }^{\mathrm{TM}} 800$, USA) kullanılmıştır. Numunelerin hazırlanmasında, yaklaşık 0,5 g mantar örneği mikrodalga fırının teflon kaplarına aktarılmış, her örneğe $10 \mathrm{~mL}$ nitrik asit ilave edilerek, mikrodalgada yakılmıştır. Örnekler, AAS cihazında her bir element için dalga boyu, spesifik lamba ve standart grafikler kullanılarak analiz edilmiştir. Çalışmalar üç tekrar şeklinde yapılmış ve çıkan sonuçların ortalaması alınmıştır. Mineral analizlerinin verileri $\mathrm{mg} / \mathrm{kg}$ olarak rapor edilmiştir.

\section{Bulgular ve Tartışma}

Doğal ortamdan toplanan $P$. eryngii ve $L$. nuda örneklerine ait ağır metal analiz sonuçları Çizelge 2'de gösterilmiştir.

Yaptığımız analizler sonucunda mantar örneklerinde farklı miktarlarda 9 çeşit ağır metal ( $\mathrm{Ni}, \mathrm{Fe}, \mathrm{Cu}, \mathrm{Zn}, \mathrm{Al}, \mathrm{Co}, \mathrm{Mn}, \mathrm{Cr}, \mathrm{Cd}$ ) tespit edilmiştir. Tüm örneklerde en fazla tespit edilen mineral $9,450-71,750 \mathrm{mg} / \mathrm{kg}$ arasında değişen miktarı ile Fe olurken, miktarı en az olan element ise 0,079$0,101 \mathrm{mg} / \mathrm{kg}$ arasında değişen miktarı ile $\mathrm{Cd}$ olmuştur. Buna ilaveten örneklerdeki diğer ağır metallerin miktarları $\mathrm{Ni}$ için 0,474-0,665 mg/kg, $\mathrm{Cu}$ için 0,520-1,545 mg/kg, Zn için 2,482-6,639 mg/kg, Al için $3,508-22,810 \mathrm{mg} / \mathrm{kg}$, Co için 0,147-0,182 $\mathrm{mg} / \mathrm{kg}, \mathrm{Mn}$ için 0,626-1,376 mg/kg, $\mathrm{Cr}$ için 0,414$0,638 \mathrm{mg} / \mathrm{kg}$ arasında dağılım göstermiştir. $P$. eryngii'nin kirli örneklerindeki ağır metal miktarı temiz örneklerine göre daha yüksek çıkmıştır. Ancak Lepista nuda'da temiz örneklerinde $\mathrm{Ni}, \mathrm{Zn}$, $\mathrm{Co}, \mathrm{Cr}$; kirli örneklerinde ise $\mathrm{Fe}, \mathrm{Cu}, \mathrm{Al}, \mathrm{Mn}$ ve $\mathrm{Cd}$ daha yüksek miktarda tespit edilmiştir (Çizelge 2 ). 
Çizelge 1. Analiz edilen makromantar örneklerinin bazı özellikleri.

\begin{tabular}{|c|c|c|c|c|}
\hline Örnekler & Familya & Lokalite & Habitat & $\begin{array}{l}\text { Fungaryum } \\
\text { No }\end{array}$ \\
\hline $\begin{array}{l}\text { P. eryngii } \\
\text { (Temiz) }\end{array}$ & Pleurotaceae & $\begin{array}{l}\text { Tokat merkez, Bozatalan köyü } \\
40^{\circ} 24^{\prime} 121^{\prime \prime K}, 036^{\circ} 26^{\prime} 164^{\prime D} \\
1262 \mathrm{~m}\end{array}$ & $\begin{array}{l}\text { Çam ormanı } \\
\text { Çayırlık alan }\end{array}$ & i\&H 68 \\
\hline $\begin{array}{l}\text { P. eryngii } \\
\text { (Kirli) }\end{array}$ & & $\begin{array}{l}\text { Tokat merkez, Pınarlı köyü } \\
40^{\circ} 21^{\prime} 406^{\prime \prime} \mathrm{K}, 036^{\circ} 43^{\prime} 465^{\prime D} \\
820 \mathrm{~m}\end{array}$ & $\begin{array}{l}\text { Yol kenarı } \\
\text { çayırlık alan }\end{array}$ & I\&H 384 \\
\hline $\begin{array}{l}\text { L. nuda } \\
\text { (Temiz) }\end{array}$ & Tricholomataceae & $\begin{array}{l}\text { Tokat merkez, Yaylacık dağı; } \\
40^{\circ} 24^{\prime} 037^{\prime \prime K}, 036^{\circ} 33^{\prime} 182^{\prime K} \text { D } \\
1497 \mathrm{~m}\end{array}$ & Çam ormanı & i\&H 351 \\
\hline $\begin{array}{l}\text { L. nuda } \\
\text { (Kirli) }\end{array}$ & & $\begin{array}{l}\text { Tokat GOP Üniversitesi kampüs } \\
\text { alanı; } \\
40^{\circ} 19^{\prime} 396^{\prime \prime} \mathrm{K}, 036^{\circ} 28^{\prime} 450^{\prime \prime D} \\
643 \mathrm{~m}\end{array}$ & $\begin{array}{l}\text { Çam ormanı } \\
\text { Yol kenarı }\end{array}$ & i\&H 370 \\
\hline
\end{tabular}

temiz: ormanlık alandan toplanmış makromantar örnekleri

kirli: yol kenarından toplanan makromantar örnekleri

Çizelge 2. Makromantar örneklerindeki bazı ağır metal içerikleri (mg/kg).

\begin{tabular}{llllllllll}
\hline Örnekler & Ni & Fe & Cu & Zn & Al & Co & Mn & Cr & Cd \\
\hline $\begin{array}{l}\text { P. eryngii } \\
\text { (temiz) }\end{array}$ & 0,474 & 14,195 & 0,520 & 2,482 & 4,512 & 0,170 & 0,895 & 0,636 & 0,079 \\
$\begin{array}{l}\text { P. eryngii } \\
\text { (kirli) }\end{array}$ & 0,665 & 71,750 & 0,537 & 3,284 & 22,810 & 0,182 & 1,376 & 0,638 & 0,088 \\
$\begin{array}{l}\text { L. nuda } \\
\text { (temiz) }\end{array}$ & 0,510 & 9,450 & 1,374 & 6,639 & 3,508 & 0,151 & 0,626 & 0,468 & 0,100 \\
$\begin{array}{l}\text { L. nuda } \\
\text { (kirli) }\end{array}$ & 0,487 & 16,270 & 1,545 & 3,777 & 6,157 & 0,147 & 0,716 & 0,414 & 0,101 \\
$\begin{array}{l}\text { dalga boyu } \\
\text { (nm) }\end{array}$ & 232 & 248,3 & 324,8 & 213,9 & 309,3 & 240,7 & 279,5 & 357,9 & 228,8 \\
\end{tabular}

Demir hemoglobin ve miyoglobin'in yapısına katıldığı gibi, oksijen ve elektronların taşınması, DNA sentezi gibi önemli metabolik olaylarda görev alan bir iz elementtir. Yeryüzünde bol miktarda bulunan bu element, vücudumuzda serbest radikaller oluşturabildiğinden ve doku hasarına yol açabildiğinden dolayı miktarı belirli sınırlar içerisinde olmalıdır (Abbaspour ve ark., 2014). Çalışma materyalimiz olan makromantar örneklerinde miktarı en fazla olan element Fe minerali olmuş ve $P$. eryngii'nin temiz örneklerinde $14,195 \mathrm{mg} / \mathrm{kg}$, kirli örneklerinde $71,750 \mathrm{mg} / \mathrm{kg} ; \mathrm{L}$. nuda'nın temiz örneklerinde $9,450 \mathrm{mg} / \mathrm{kg}$, kirli örneklerinde ise $16,270 \mathrm{mg} / \mathrm{kg}$ olarak ölçülmüştür. Demirden sonra örneklerimizde miktarı fazla olan mineraller $\mathrm{Al}$ ve $\mathrm{Zn}$ olmuştur. $\mathrm{Bu}$ minerallerin miktarları $P$. eryngii'nin temiz örneklerinde 4,512 $\mathrm{mg} / \mathrm{kg}$ (Al) ve $2,482 \mathrm{mg} / \mathrm{kg}(\mathrm{Zn})$; kirli örneklerinde $22,810 \mathrm{mg} / \mathrm{kg}$ (Al); 3,284 mg/kg (Zn); L. nuda'nın temiz örneklerinde $6,639 \mathrm{mg} / \mathrm{kg}(\mathrm{Zn})$ ve 3,508 $\mathrm{mg} / \mathrm{kg}$ (Al); kirli örneklerinde ise $6,157 \mathrm{mg} / \mathrm{kg}$ (Al) ve $3,777 \mathrm{mg} / \mathrm{kg}(\mathrm{Zn})$ olarak belirlenmiştir (Şekil 1,2). P. eryngii ve aynı familyada yakın bir tür olan Pleurotus ostreatus (Jacq.) P. Kumm.'un ağır metal içeriklerini belirlemek için yapılan bazı çalışmalar Çizelge 3'de gösterilmiştir.

Zhu ve ark. (2011) tarafından P. eryngii'nin biriktirdiği ağır metalleri tespit etmek için yapılan analizlerde miktarı en fazla olan element Zn (57,9 $\mathrm{mg} / \mathrm{kg})$ ve $\mathrm{Fe}(242 \mathrm{mg} / \mathrm{kg})$ olarak tespit edilmiş, bunları sırasıyla $\mathrm{Cr}, \mathrm{Mn}, \mathrm{Cu}, \mathrm{Ni}$ ve $\mathrm{Cd}$ takip etmiştir (Çizelge 3). Bizim analizlerimizde de buna uygun olarak $P$. eryngii'nin hem temiz hem de kirli örneklerinde $\mathrm{Fe}, \mathrm{Al}$ ve $\mathrm{Zn}$ miktarı en bol olan elementler olarak ölçülmüştür. Bizim örneklerimizdeki Cd miktarı bu çalışmanın sonuçlarına göre daha yüksek çıkarken diğer minerallerin miktarı daha düşük çıkmıştır. Yine aynı 
tür mantar için Altıntığ ve ark. (2017) tarafından Indüktif Eşleşmiş Plazma-Optik Emisyon Spektrometresi (ICP-OES) cihazı ile yaptıkları bir çalışmada Fe $(149,90 \mathrm{mg} / \mathrm{kg}), \mathrm{Ni}(24,66 \mathrm{mg} / \mathrm{kg}), \mathrm{Zn}$ $(80,6 \mathrm{mg} / \mathrm{kg}), \mathrm{Cr}(14,72 \mathrm{mg} / \mathrm{kg})$ ve $\mathrm{Cu}(74,16 \mathrm{mg} / \mathrm{kg})$ olarak tespit edilmiştir. Bu çalışmada da Fe ve $\mathrm{Zn}$, miktarı en fazla olan elementler olarak belirlenmiştir. Bizim örneklerimizdeki ağır metallerin miktarı Altıntığ ve ark. (2017) tarafından yapılan çalışmaya göre daha düşük çıkmıştır. $P$. ostreatus ile ilgili yapılan çalışmalarda $\mathrm{Fe}, \mathrm{Zn}, \mathrm{Cu}$ ve $\mathrm{Mn}$ en bol bulunan mineraller olmuştur (Çizelge 3 ). Bizim yaptığımız çalışmada Al 3,508-22,810 mg/kg arasında değişen miktarlarda, Co ise 0,147-0,182 $\mathrm{mg} / \mathrm{kg}$ arasında değişen miktarlarda tespit edilirken, Çizelge 3'de yer alan çalışmalarda Al ve Co miktarlarına bakılmamış veya tespit edilememiştir. Çalışmamızın diğer bir materyali olan $L$. nuda'nın temiz ve kirli örneklerindeki ağır metal miktarı Çizelge 2 ve Şekil 2'de verilmiştir. Mineraller içerisinde $\mathrm{Ni}, \mathrm{Zn}$, Co ve $\mathrm{Cr}$ sırasıyla 0,510; 6,639; 0,151; 0,468 $\mathrm{mg} / \mathrm{kg}$ ile temiz örneklerde yüksek çıkarken; $\mathrm{Fe}, \mathrm{Cu}, \mathrm{Al}, \mathrm{Mn}$ ve $\mathrm{Cd}$ ise 16,$270 ; 1,545 ; 6,157 ; 0,716 ; 0,101 \mathrm{mg} / \mathrm{kg}$ ile kirli örneklerinde daha yüksek çıkmıştır. Ouzouni ve ark. (2009) tarafından L. nuda üzerine yapılan bir çalışmada $\mathrm{Cu}, \mathrm{Fe}, \mathrm{Zn}, \mathrm{Mn}, \mathrm{Cd} \mathrm{Pb}$ ağır metallerinin miktarları ölçülmüştür. Bunların içerisinde miktarı en fazla olan element $98,99 \mathrm{mg} / \mathrm{kg}$ ile $\mathrm{Zn}$ olmuştur. Bunu 75,06 mg/kg ile Cu; 74,6 mg/kg ile Fe; 33,65 $\mathrm{mg} / \mathrm{kg}$ ile $\mathrm{Mn}$ takip etmiştir. Bizim çalışmamızda miktarı en fazla olan element Fe olarak ölçülmüş, bunu sırasıyla temiz örneklerde $\mathrm{Zn}$ ve $\mathrm{Al}$, kirli örneklerde Al ve Zn takip etmiştir (Şekil 2). Aynı tür mantar kullanılarak yapılan başka bir çalışmada $\mathrm{Cu}$ miktarı 117,7 mg/kg; Zn değeri 182,1 mg/kg olarak ölçülmüştür (Alonso ve ark., 2003). L. nuda bazidiyokarpları kullanılarak Yamaç ve ark. (2007) tarafından ICP-OES cihazı kullanılarak yapılan bir çalışmada 8 farklı ağır metal (Pb, Cd, $\mathrm{Zn}, \mathrm{Fe}, \mathrm{Mn}$, $\mathrm{Cu}, \mathrm{Cr}, \mathrm{Ni})$ tespit edilmiştir. Bunların içinde miktarı en bol olan $480 \mathrm{mg} / \mathrm{kg}$ ile Mn olmuş, bunu 144,20 $\mathrm{mg} / \mathrm{kg}$ ile Cu ve $121 \mathrm{mg} / \mathrm{kg}$ ile Zn takip etmiştir.

Makromantarların absorbe ettiği ağır metal miktarını belirlemeye yönelik yapılan başka bir çalışmada L. nuda örneklerinde fazla miktarda tespit edilen mineraller 337,64; 60,95; 55,45; 34,94; 15,15 $\mu \mathrm{g} / \mathrm{g}$ miktarları ile sırasıyla Fe, Zn, Cu, $\mathrm{Mn}$ ve $\mathrm{Cr}$ olmuştur (Işıldak ve ark., 2007).

Doğal ortamdan toplanan mantarlar besin olarak kullanıldığında biriktirdikleri ağır metallerde besin zincirine katılmakta ve biyolojik birikime katkı sağlamaktadır. Makromantarlarda biriken metal oranında yaşadığı çevrenin özellikleri, mantarın morfolojik özellikleri ve beslenme şekli (mikorizal veya saprofit) etkili olmaktadır. Buna ilaveten bazidiyokarplarındaki metal miktarı, bunların emilimini ve birikme oranını etkileyen birçok faktör nedeniyle (örneğin toprağın $\mathrm{pH}$, redoks potansiyeli, organik madde içeriği, metal iyonlarının alınımı esnasındaki rekabet) tür içinde geniş bir aralıkta değişebilmektedir (Garcia ve ark., 1998; Ángeles García ve ark., 2009; Kalač 2009).

Çizelge 3. $P$. eryngii ve P.ostreatus'un ağır metal içeriklerine yönelik bazı literatür verileri (mg/kg).

\begin{tabular}{|c|c|c|c|c|c|c|c|c|}
\hline Literatür & Örnekler & $\mathrm{Ni}$ & $\mathrm{Fe}$ & $\mathrm{Cu}$ & $\mathrm{Zn}$ & Mn & $\mathrm{Cr}$ & Cd \\
\hline \multirow{2}{*}{$\begin{array}{l}\text { Zhu ve ark. } \\
\text { 2011) }\end{array}$} & P. eryngii & 0,83 & 242 & 6,83 & 57,9 & 13,5 & 22,3 & 0,06 \\
\hline & P. ostreatus & 1,50 & 95,7 & 26,7 & 48,4 & 31,4 & 16,3 & 0,28 \\
\hline \multirow[t]{2}{*}{ Altıntığ ve ark. 2017} & P. eryngii & 24,66 & 149,90 & 74,16 & 80,6 & - & 14,72 & - \\
\hline & P. ostreatus & 25,13 & 86,90 & 76 & 53,47 & - & 13,97 & - \\
\hline İta ve ark. 2006 & P. ostreatus & - & 407,7 & 45,9 & 90,6 & 39,8 & - & 0,3 \\
\hline \multirow[t]{2}{*}{ Akyüz ve Kırbağ. 2010} & $\begin{array}{l}\text { P. ostreatus } \\
\text { (Elazığ örneği) }\end{array}$ & - & 718 & 10,5 & 46 & 12 & 5,4 & 0,75 \\
\hline & $\begin{array}{l}\text { P. ostreatus } \\
\text { (Diyarbakır } \\
\text { örneği) }\end{array}$ & & 838 & 14 & 44,5 & 65,4 & 11,5 & 1,65 \\
\hline
\end{tabular}

\section{Sonuç ve Öneriler}

Mantarların mineral içeriğini tespit etmeye yönelik yapılan birçok çalışma, bunların çevre kirliliği açısından biyoindikatör olabileceklerini göstermiştir. Makromantarlar sporokarplarının yüksek birikim yapabilme özellikleri sayesinde kirli veya kirlenmemiş alanları ayırt etme konusunda bize faydalı olabilir (Kalač and Svoboda, 2000). Ağır metaller besin zincirine değişik yollardan katılmakta ve canlıların dokularında birikebilmektedir. Bu biyolojik birikimden en fazla etkilenenler insanda olduğu gibi besin zincirinin en sonunda bulunan canlılar olmaktadır. Bu çalışmada AAS cihazı kullanılarak $P$. eryngii ve $L$. nuda örneklerinde bazı toksik elementler $(\mathrm{Cr}$ ve $\mathrm{Cd})$ ve bazı iz elementler (Fe, Co, $\mathrm{Al}, \mathrm{Ni}, \mathrm{Cu}, \mathrm{Mn}, \mathrm{Zn}$ ) farklı 
miktarlarda tespit edilmiştir. Mantar örneklerinin bazıları (temiz örnekler) şehir yaşamı, trafik ve endüstri gibi kirliliğe neden olan faktörlerden uzak lokalitelerden toplanırken, bazıları yol kenarlarına ve yaşam alanlarına (kirli örnekler) yakın lokalitelerden toplanmıştır. $P$. eryngii'nin temiz örneklerindeki tüm ağır metal miktarları kirli örneklere göre daha düşük çıkmıştır. L.nuda'da ise temiz örneklerde $\mathrm{Fe}, \mathrm{Cu}, \mathrm{Al}, \mathrm{Mn}, \mathrm{Cd}$ miktarı kirli örneklere göre daha düşük çıkmıştır. L. nuda'nın temiz örneklerinde ekolojik ortamından ve yetiştiği toprak yapısından kaynaklı daha fazla miktarda Ni, $\mathrm{Zn}$, Co ve $\mathrm{Cr}$ gözlemlenmiştir. Doğal ve temiz ormanlık alanlardan toplanan mantar örneklerinin tüketilmesinin daha uygun olacağı görülmektedir. Yapmış olduğumuz çalışma ve literatür bilgileri doğal olarak yetişen mantarların ağır metaller için birer biyoakümülatör olabileceğini göstermiştir.

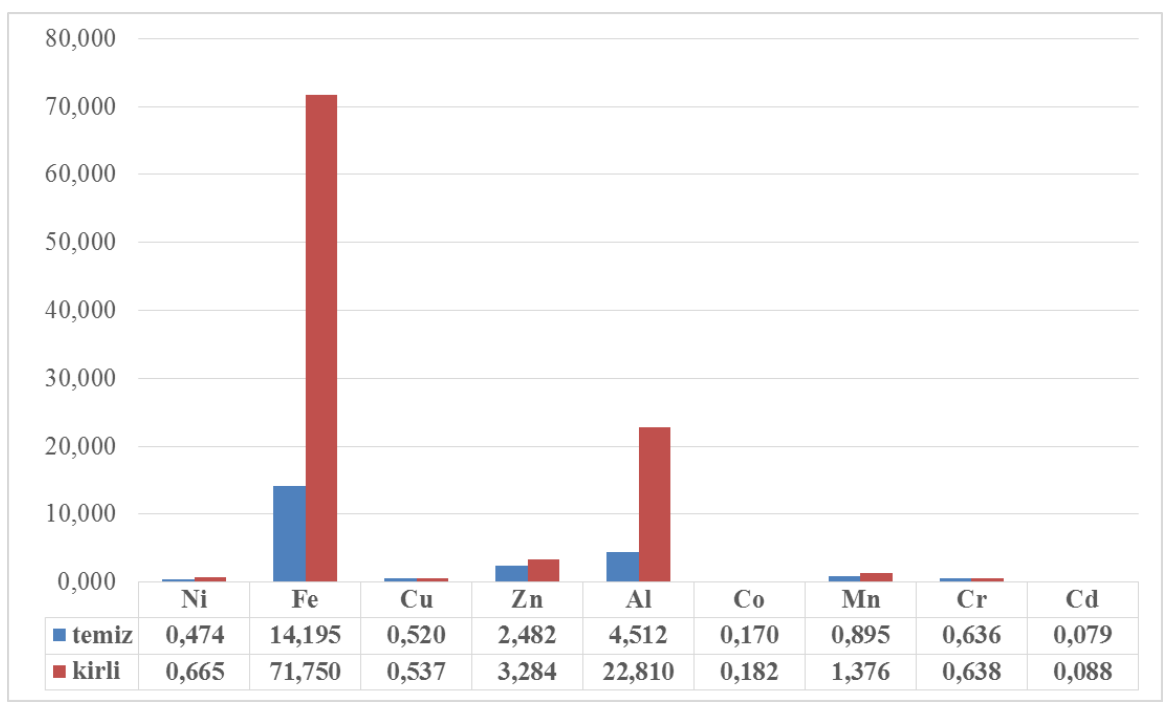

Şekil 1. P. eryngii'nin temiz ve kirli örneklerindeki ağır metal miktarı

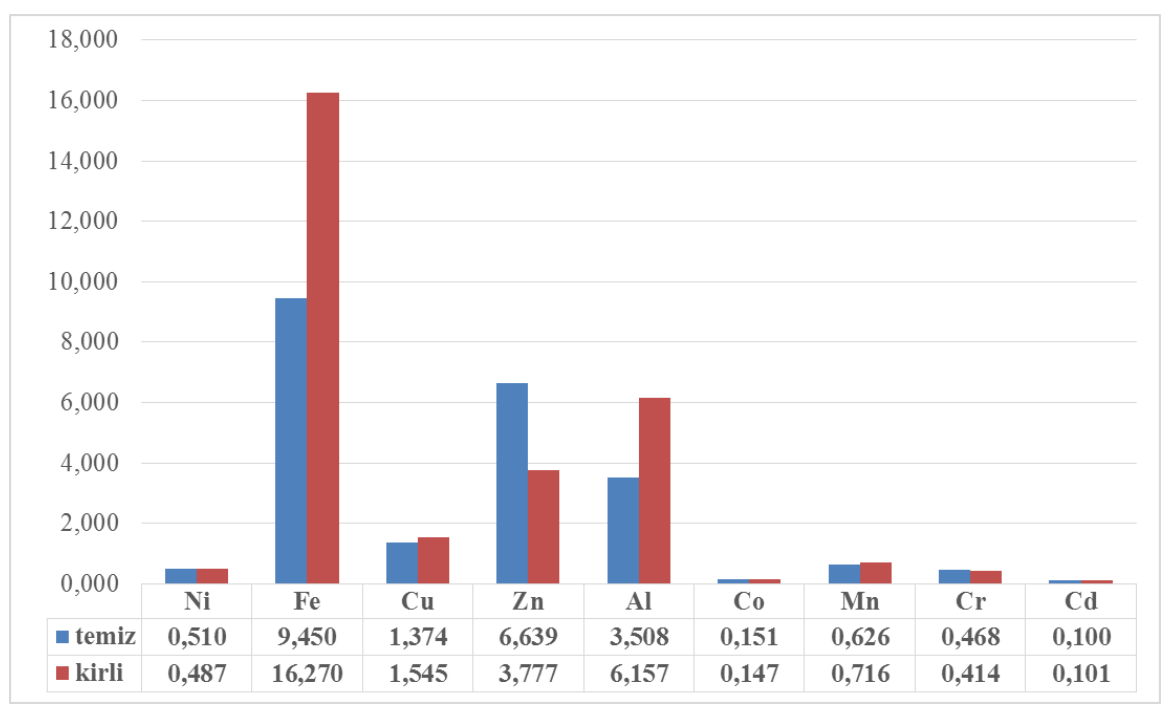

Şekil 2. L. nuda'nın temiz ve kirli örneklerindeki ağır metal miktarı

Teşekkür: Bu çalışmamızda mantar örneklerinin ağır metal analizinde yardımlarını esirgemeyen Bingöl Üniversitesi Merkezi Araştırma Laboratuvarı yöneticileri ve uzman personeline teşekkür ederiz.
Çıkar Çatışması Beyanı: Makale yazarları aralarında herhangi bir çıkar çatışması olmadığını beyan ederler.

Araştırmacıların Katkı Oranı Beyan Özeti: Yazarlar makaleye eşit oranda katkı sağlamış olduklarını beyan ederler. 


\section{Kaynaklar}

Abbaspour, N., Hurrell, R. ve Kelishadi, R. 2014. Review on iron and its importance for human health. Journal of Research in Medical Sciences, 19: 164-174.

Akyüz, M. ve Kırbağ, S. 2010. Nutritive value of wild edible and cultured mushrooms. Turkish Journal of Biology, 34: 97-102.

Altıntığ, E., Hişir, M.E. ve Altundağ, H. 2017. Determination of $\mathrm{Cr}, \mathrm{Cu}, \mathrm{Fe}, \mathrm{Ni}, \mathrm{Pb}$ and $\mathrm{Zn}$ by ICP-OES in mushroom samples from Sakarya, Turkey. Sakarya Üniversitesi Fen Bilimleri Enstitüsü Dergisi, 21(3): 496-504.

Alonso, J., García, M.A., Pérez-López, M. ve Melgar, M.J. 2003. The Concentrations and Bioconcentration Factors of Copper and Zinc in Edible Mushrooms. Archives of Environmental Contamination and Toxicology, 44: 180-188.

Ángeles García, M., Alonso, J. ve Melgar, J.M. 2009. Lead in edible mushrooms: Levels and bioaccumulation factors. Journal of Hazardous Materials, 167: 777-783.

Bengü, A.Ş., Çınar Yılmaz, H., Türkekul, İ. ve Işık, H. 2019. Doğadan Toplanan ve Kültürü Yapılan Pleurotus ostreatus ve Agaricus bisporus Mantarlarının Toplam Protein, Vitamin ve Yağ Asidi İçeriklerinin Belirlenmesi. Türk Tarım ve Doğa Bilimleri Dergisi, 6(2): 222229.

Duruibe, J.O., Ogwuegbu, M.O.C. ve Egwurugwu, J.N. 2007. Heavy metal pollution and human biotoxic effects. International Journal of Physical Sciences, 2(5): 112-118.

Garcia, M.A., Alonso, J., Fernandez, M. I. ve Melgar, M.J. 1998. Lead content in edible wild mushrooms in Northwest Spain as indicator of environmental contamination. Archives Environmental Contaminatian and Toxicology, 34: 330-335.

Guerra, F., Trevizam, A.R., Muraoka, T., Marcante, N.C. ve Canniatti-Brazaca, S.G. 2012. Heavy metals in vegetables and potential risk for human health. Scientia Agricola, 69(1): 5460.

Işıldak, Ö., Türkekul, İ., Elmastaş, M. ve AboulEnein, H.Y. 2007. Bioaccumulation of Heavy Metals in Some Wild-Grown Edible Mushrooms. Analytical Letters, 40: 10991116.

Ita, B.N., Essien, J.P. ve Ebong, G.A. 2006. Heavy Metal Levels in Fruiting Bodies of Edible and Non-edible Mushrooms from the Niger Delta Region of Nigeria. Journal of Agriculture \& Social Sciences, 2(2): 84-87.
Järup, L. 2003. Hazards of heavy metal contamination. British Medical Bulletin, 68(1): 167-182.

Kalač, P. 2001. A review of edible mushroom radioactivity. Food Chemistry, 75: 29-35.

Kalač, P. 2009. Chemical composition and nutritional value of European species of wild growing mushrooms: a review. Food Chemistry, 113: 9-16.

Kalač, P. ve Svoboda, L. 2000. A review of trace element concentrations in edible mushrooms. Food Chemistry, 69: 273-281.

Kupchyk, O. 2018. Determining Heavy Metals in Mushroom Samples by Stripping Voltammetry. Food Science and Technology, 12(2): 62-67.

Manzi, P., Aguzzi, A. ve Pizzoferrato, L. 2001. Nutritional value of mushrooms widely consumed in Italy. Food Chemistry, 73, 321325.

Pekşen, A. 2013. Mantarların İnsan Hayatı ve Sağlığındaki Yeri. Bahçe Haber, 2(1), 10-15.

Pekşen, A., Yakupoğlu, G. ve Kibar, B. 2008. Some Chemical Components of Lactarius pyragalus from Diverse Locations. Asian Journal of Chemistry, 20(4): 3109-3114.

Širić, I., Humar, M., Kasap, A., Kos, I., Mioč, B. ve Pohleven, F. 2016. Heavy metal bioaccumulation by wild edible saprophytic and ectomycorrhizal mushrooms. Environmental Science and Pollution Research, 23: 18239-18252.

Orsine, J.V.C., Novaes, M.R.C.G. ve Asquieri, E.R. 2012. Nutritional value of Agaricus sylvaticus; mushroom grown in Brazil. Nutrición Hospitalaria, 27(2): 449-455.

Ouzouni, P.K., Petridis, D., Koller, W.D. ve Riganakos, K.A. 2009. Nutritional value and metal content of wild edible mushrooms collected from West Macedonia and Epirus, Greece. Food Chemistry, 115:1575-1580.

Valverde, M.E., Hernández-Pérez, T. ve ParedesLópez, O. 2015. Edible mushrooms: Improving human health and promoting quality life. International Journal of Microbiology, 2015: 1-14.

Yamaç, M., Yıldız, D., Sarıkürkcü, C., Çelikkollu, M. ve Solak, M.H. 2007. Heavy metals in some edible mushrooms from the Central Anatolia, Turkey. Food Chemistry, 103: 263267.

Zhu, F., Qu, L., Fan, W., Qiao, M., Hao, H. ve Wang, X. 2011. Assessment of heavy metals in some wild edible mushrooms collected from Yunnan Province, China. Environmental Monitoring and Assessment, 179: 191-199. 